\title{
Post-industrial Cultural Heritage Sites in the Katowice conurbation, Poland
}

\author{
Marzena Lamparska
}

Department of Economic Geography, Faculty of Earth Sciences, University of Silesia, Będzińska Str. 60, 41-200 Sosnowiec, Poland E-mail address: marzenalamparska@gmail.com

\begin{abstract}
The Katowice conurbation comprises of towns which have developed because of the mining of metal ores, coal and raw rock materials. The development of mining and industry which have lasted for centuries has resulted in the specific character of the landscape of the area with its typical indicators such as housing estates built for the working class, winding towers, chimneys of steelworks, coking plants, power stations, drifts, quarries, etc. The residents of mining communities, and local governments within the conurbation, which have developed owing to mining, are aware of the impending economic slowdown after liquidation of coal mines. Therefore, development of the service sector, including tourism, based on postindustrial facilities can become an important factor in restructuring the economy. This article presents a classification of post-industrial cultural heritage sites prepared for the purpose of geotourism. Several categories of such sites have been distinguished: 1) historic mining landscapes, 2) places adapted for recreation, 3) places documenting changes in the groundwater environment, 4) characteristic Silesian landscapes, places commemorating stages of development of the mining industry, 5) post-mining sites adapted for service, commercial or residential purposes, 6) mining museums and open-air museums. The described post-mining sites occur in different parts of the Katowice conurbation; therefore, linking them by a system of tourist trails and surrounding them by zones of protected landscape will be an important task for the future. Material remains of the industrial culture preserved within the Katowice conurbation, despite their diversity, form complexes of monuments complementary to those that can be found in the entire industrialized Europe. Therefore, the industrial heritage in the area of the Katowice conurbation is an important part of the European, supranational heritage.
\end{abstract}

KEY WORDS: post-mining areas, landscape, housing estates, geotourism

\section{Introduction}

The Katowice conurbation comprises of towns which have developed in those areas where mining of metal ores, coal and raw rock materials have occurred. The exploitation of mineral resources lasted for many centuries and took place with various intensity and used different methods of extraction in different phases of development of the mining industry, and these have led to changes in the environment mainly in geomorphology, water regimes and vegetation. As far as the social sphere is concerned, mining contributed to the creation of a specific work ethos, while the development of mines accompanied by the development of housing estates and industrial constructions contributed to the division and evaluation of social space in the towns, which has not been observed on such a large scale anywhere else in Poland. Development of new industrial plants, working class settlements, and industrial towns gave the sites in Upper Silesia, especially in the area of the Katowice conurbation, notable industrial character. This appears in the form of working class settlements, communication systems, and characteristic "icons" defining the quality of the space. These are the winding towers of mine shafts, chimneys of steelworks, coking plants and power plants, and finally working class housing estates of compact urban form, coexisting alongside the industrial and communication areas. These forms will slowly blur over time, as the mining boom in the conurbation has already finished (LAMPARSKAWiELAND, 2006). Numerous coal mines have been closed because resources have been depleted. 
Most of the remaining collieries will cease to exist in this century.

Residents and self-governments of the mining communities in the region, including the ones within the conurbation, which have been developing on the basis of the operating mines, are aware of the impending economic slowdown. A number of adverse social and economic phenomena, including high unemployment, will occur as a result of closing the existing mines. The effects of unemployment, which occurred after the restructuring of the coal mining industry, are still strongly felt in the mining communities. Hence, local governments and residents have to be prepared for the reconstruction of the economy after the closure of the mines in their areas. A significant role in this reconstruction can be played by development of the service sector, including tourism based on these post-industrial sites.

\section{An attempt to classify post-mining sites}

The complexity and multi-dimensionality of the adaptation of the problems of post-industrial sites in Silesia, and in some European basins, were mentioned by DWUCET \& PUKOWSKA - MitKA (2007). In the market economy, the competition will be won be those communities which are able to advertise their advantages effectively. Due to the large number of valuable cultural heritage postmining sites a system of classification should be proposed (LAMPARSKA-STOBIECKA, 2008). The author's attempt to classify the sites for geotourism purposes is presented in Tab. 1 and their location in the Katowice conurbation is shown in Fig. 1. The following types of sites have been distinguished in the classification:

$\mathrm{P}$ - underground facilities

$\mathrm{O}$ - opencast/surface facilities

$\mathrm{T}$ - facilities currently used for geotourism

$\mathrm{Z}$ - developed sites

$\mathrm{R}$ - revitalised or artificially reclaimed sites

$\mathrm{N}$ - naturally revitalised sites

S (I-IV) - the degree of usefulness of a particular facility or site for services, especially for geotourism

$S$ (I) - sites or facilities used mainly for geotourism $S$ (II) - sites or facilities used for recreation, geotourism, located off the known tourist trails S (III) - sites or facilities not used for geotourism, but of great importance for the cultural landscape of Upper Silesia

S (IV) - sites or facilities of historic, documentary value, but of no importance for geotourism.

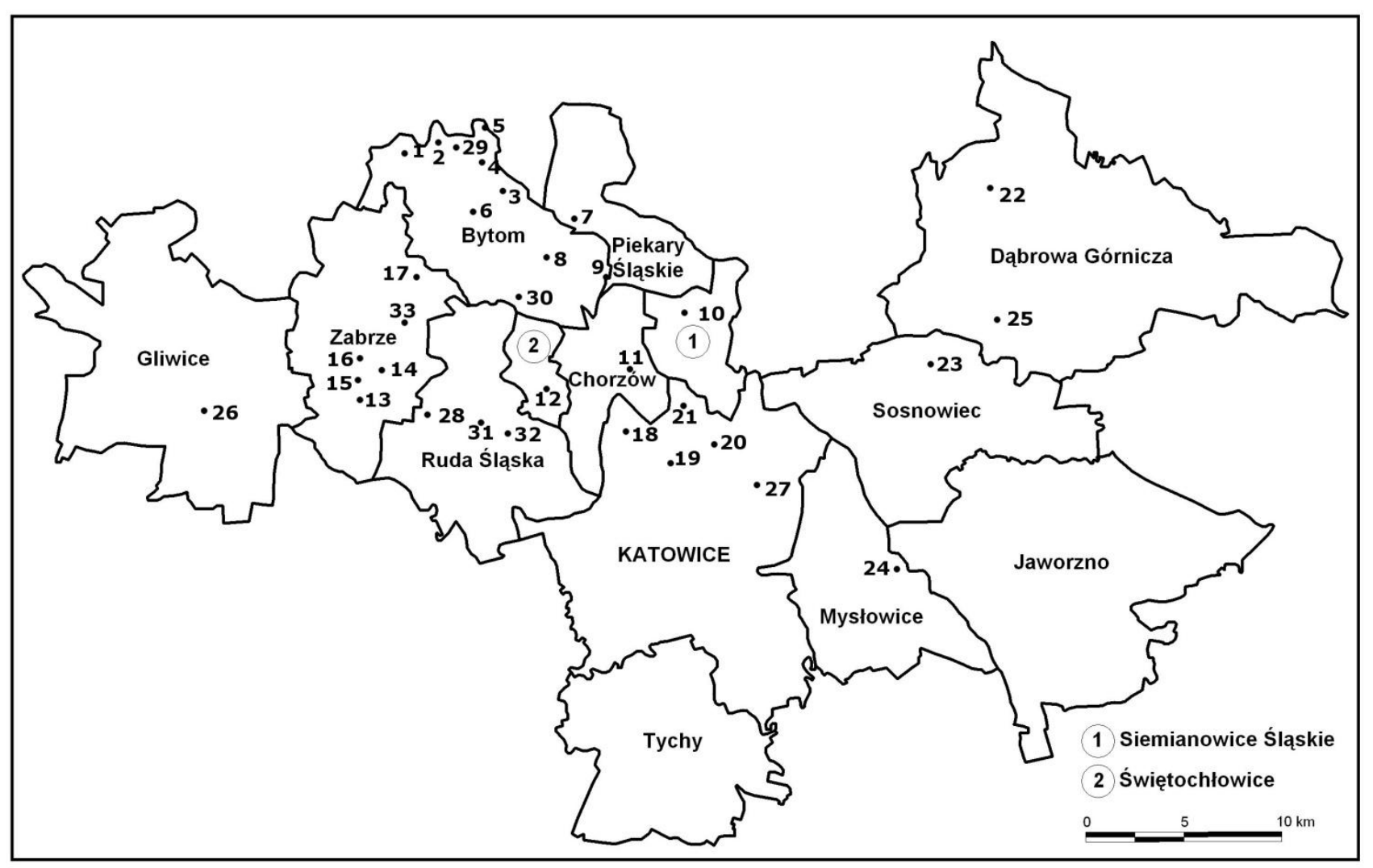

Fig. 1. Location of post-industrial cultural sites in the Katowice conurbation (after Lamparska-Stobiecka, 2008) 
Table 1. Classification of post-industrial heritage sites within the area of the Katowice conurbation (prepared by the author after Kossuth, 1965; Krygier et al., 1971; Jaros, 1984; Lamparska-Wieland, 2000, 2001, 2004; Lamparska-Wieland et al., 2002)

\begin{tabular}{|c|c|c|c|}
\hline No. & Site name & Symbol & Notes \\
\hline 1. & $\begin{array}{l}\text { The area of abandoned workings and subsidence of the } 18^{\text {th }}-19^{\text {th }} \\
\text { century in the area of Górniki, Stolarzowice and Bytom }\end{array}$ & $\begin{array}{l}\text { O/P.N.S } \\
\text { (IV) }\end{array}$ & \\
\hline 2. & $\begin{array}{l}\text { The area of abandoned workings and subsidence of the } 16^{\mathrm{th}}-18^{\text {th }} \\
\text { century in the natural reserve of beech trees "Segiet", Bytom }\end{array}$ & O/P.N.S (I) & \\
\hline 3. & The area of slag heaps - coal, ore on the border of Radzionków and Bytom & O.R.S (IV) & \\
\hline 4. & $\begin{array}{l}\text { Park "Grota" in Sucha Góra in Bytom, in the area of flooded } \\
\text { opencast mine of calamine }\end{array}$ & O.Z.T.S (II) & The place of worship and recreation \\
\hline 5. & $\begin{array}{l}\text { A granite block of benchmark } 0 \text { of the geodetic network in Sucha } \\
\text { Góra, Bytom }\end{array}$ & O.N.S (III) & $\begin{array}{l}\text { The network was used till the last half } \\
\text { of the } 19^{\text {th }} \text { century and is still in use in } \\
\text { mines in Upper Silesia }\end{array}$ \\
\hline 6. & $\begin{array}{l}\text { A strip of abandoned workings of the } 19^{\text {th }} \text { century lead and zinc } \\
\text { mines, currently the largest area of subsidence troughs between } \\
\text { Miechowice and Piekary Śląskie }\end{array}$ & $\begin{array}{l}\text { O.R/N.S } \\
\text { (IV) }\end{array}$ & \\
\hline 7. & $\begin{array}{l}\text { The Szarlejka artificial riverbed transferred in the } 19^{\text {th }} \text { century and } \\
\text { the canal partially running under the housing estate Szarlej in Piekary } \\
\text { Śląskie }\end{array}$ & O/P.Z.S (III) & $\begin{array}{l}\text { The Szarlejka riverbed was transferred to } \\
\text { expand „Bleyscharley” the largest opencast } \\
\text { mine in Europe in the } 19^{\text {th }} \text { century }\end{array}$ \\
\hline 8. & $\begin{array}{l}\text { The „Bolko” shaft in the lead and zinc mine in Bytom with a } \\
\text { residential loft }\end{array}$ & P.Z.S (II) & $\begin{array}{l}\text { The central pump station, draining the } \\
\text { workings of post-ore mines }\end{array}$ \\
\hline 9. & $\begin{array}{l}\text { "Żabie Doły" in Brzeziny Śl. within the area of Piekary Śl. and Bytom - } \\
\text { Nature-Landscape Complex in the area of subsidence troughs surrounded } \\
\text { by slag heaps of settling ponds of the closed zinc mine "Orzeł Biały" }\end{array}$ & $\begin{array}{l}\text { O.Z.T.N.S } \\
\text { (II) }\end{array}$ & \\
\hline 10. & $\begin{array}{l}\text { The shaft “Kryspin” of the closed colliery „Michałkowice” in } \\
\text { Siemianowice Śl., and historic surface facilities }\end{array}$ & O.R.S (III) & $\begin{array}{l}\text { Planned museum and mining traditions } \\
\text { centre }\end{array}$ \\
\hline 11. & $\begin{array}{l}\text { The reinforced concrete winding tower in the "Prezydent Coal Mine" } \\
\text { in Chorzów }\end{array}$ & O.S (III) & \\
\hline 12. & $\begin{array}{l}\text { The historic winding towers in the closed mine "Polska" in } \\
\text { Świętochłowice }\end{array}$ & O.S (III) & \\
\hline 13. & Mining Heritage Park “Guido” in Zabrze & P.T.Z.S (I) & The level $317 \mathrm{~m}$ under adaptation \\
\hline 14. & Underground Heritage Park "Królowa Luiza" in Zabrze & P/O.T.Z.S (I) & \\
\hline 15. & Mining Museum in Zabrze & O.T.Z.S (I) & \\
\hline 16. & $\begin{array}{l}\text { Królewska Główna Sztolnia Dziedziczna (the Main Adit) in Zabrze, the } \\
\text { shaft "Carnall" and a steam powered hoist machine }\end{array}$ & $\begin{array}{l}\text { O/P.R.T.S } \\
\text { (I) }\end{array}$ & $\begin{array}{l}\text { The underground part under } \\
\text { revitalisation process }\end{array}$ \\
\hline 17. & $\begin{array}{l}\text { Historic facilities of the main part of the colliery "Jadwiga" } \\
\text { (Pstrowski) in Zabrze }\end{array}$ & O.Z.S (IV) & $\begin{array}{l}\text { The buildings of pithead, lamp room and } \\
\text { badge room etc. }\end{array}$ \\
\hline 18. & $\begin{array}{l}\text { The historic building of the 19th century pumping station in } \\
\text { closed "Kleofas Coal Mine" and modern discharge water intake }\end{array}$ & O.Z.S (IV) & \\
\hline 19. & $\begin{array}{l}\text { The plaque commemorating the death of } 114 \text { miners in } 1874 \text { in the } \\
\text { closed mine "Kleofas (Cezar)". Transferred to St. Joseph Church in } \\
\text { Katowice-Załęże }\end{array}$ & O.Z.S (II) & \\
\hline 20. & $\begin{array}{l}\text { The complex of surface facilities of the closed colliery "Katowice" } \\
\text { in Katowice }\end{array}$ & O.Z.S (II) & \\
\hline 21. & The winding tower in a shopping centre Silesia City Centre in Katowice & O.Z.S (I) & \\
\hline 22. & $\begin{array}{l}\text { The water sports centre "Pogoria" in backfilling sand excavations in } \\
\text { Dąbrowa Górnicza }\end{array}$ & O.Z.T.S (I) & \\
\hline 23. & $\begin{array}{l}\text { The winding tower and the deep pumping station for discharge } \\
\text { water in the closed mine "Sosnowiec" }\end{array}$ & O.Z.S (III) & Under revitalisation \\
\hline 24. & $\begin{array}{l}\text { A high bank of the Przemsza with outlets of the adit in Mysłowice- } \\
\text { Brzęczkowice }\end{array}$ & $\begin{array}{l}\text { P/O.N.S } \\
\text { (IV) }\end{array}$ & \\
\hline 25. & A training drift "Sztygarka" in Dąbrowa Górnicza & P.T.Z.S (I) & \\
\hline 26. & Colliery facilities of the closed "Gliwice Coal Mine" in Gliwice & O.Z.R.S (IV) & \\
\hline 27. & $\begin{array}{l}\text { Nikiszowiec and Giszowiec - the } 19^{\text {th }} / 20^{\text {th }} \text { housing estates of } \\
\text { "Wieczorek Coal Mine" in Katowice }\end{array}$ & O.Z.S (II) & \\
\hline 28. & $\begin{array}{l}\text { The underground channel of the Kochłówka under the } \\
\text { "Bielszowice" colliery in Ruda Śląska }\end{array}$ & O.N.S (IV) & \\
\hline 29. & "Dolomity" a winter sports centre in Blachówka in Bytom & O.Z.R.S (I) & \\
\hline 30. & $\begin{array}{l}\text { The head-frame of the "Krystyna" shaft in "Szombierki Coal Mine" } \\
\text { in Bytom }\end{array}$ & O.Z.R.S (III) & Under revitalization \\
\hline 31. & $\begin{array}{l}\text { The head-frame of the "Alfred" shaft in the closed mine "Śląsk" in } \\
\text { Ruda Śląska }\end{array}$ & O.Z.R.S (III) & \\
\hline 32. & $\begin{array}{l}\text { A surface part (roznos) of the water adit "Lazarus" in Ruda Śląska- } \\
\text { Wirek }\end{array}$ & $\begin{array}{l}\text { O.R/N.S } \\
\text { (IV) }\end{array}$ & $\begin{array}{l}\text { Only the final part on the Kochłówka is } \\
\text { accessible }\end{array}$ \\
\hline 33. & The historic baths in "Concordia Coal Mine" in Zabrze & O.Z.S (III) & \\
\hline
\end{tabular}




\section{Characteristics of particular categories of mining facilities}

\subsection{Historic post-mining landscapes}

The first group (category) of sites comprises historic post-mining landscapes (LAMPARSKAWiELAND, 2006) characterized by a specific originality and advanced processes of renaturalization. Abandoned workings (ring-shaped, low slag heaps) and sink-holes may be included in this group. They were formed between Górniki and Stolarzowice in Bytom in the period of the $18^{\text {th }}$ and the $20^{\text {th }}$ century. The areas, situated on both sides of the road Zabrze - Tarnowskie Góry, are covered with grassland vegetation and partly afforested. They were the areas where ore mining was started in the $15^{\text {th }}$ century. In the $19^{\text {th }}$ century, when zinc-lead ores were exploited, they were the mining fields of "Verona" and "Planet" mines. After ceasing exploitation in the 1920s, the areas have been the subject of re-naturalisation processes and are partly afforested. The varied relief, rich vegetation and occurrence of small water reservoirs of anthropogenic origin have made the places become a land of self-generated re-naturalization processes. The area of the natural reserve "Segiet" is an example of even more developed, richer re-naturalization, including restoration of the original plant communities (LAMPARSKA - WIELAND, 2003; CABAŁA ET AL., 2006) (Fig. 2).

The area of slag heaps in Dąbrowa Bytomska formed a different kind of post-mining landscape. Here, the remains of ore mining overlap areas of coal mining dumps. Within the area of several hectares, different types of re-naturalization of anthropogenic forms, and different stages of succession of different groups of plants at various stages of development can be found. It is a special landscape area for naturalists. A very important natural and landscape border in the northern range of coal deposits is located in the area of the slag heaps.

The area of the largest subsidence, between Piekary Śląskie and Bytom-Miechowice, is another example of a historic post-mining landscape that has been shaped by ore mining in the nineteenth century and coal mining at the end of the twentieth century. Numerous lakes have been formed there in the deep and vast subsidence troughs (SOLARSKI, 2013). In the nineteenth century the deposits of zinc and lead were exploited in the area, after that many abandoned workings were deserted. A lot of the abandoned workings are located within the lakes, forming small islands.

The area of "Żabie Doły" on the border of Bytom and Piekar Śląskie is a place where the renaturalization processes of elements of inanimate and animate influenced the characteristic features of the brownfield landscape (DULIAS, 2008). These are the areas where ore and coal were excavated. Settling ponds, water reservoirs in subsidence troughs separated by railway embankments, are characteristic parts of the landscape there. Numerous species of birds, including protected ones, have found very good conditions for breeding there. The area has become an increasingly popular place for recreation and a research site for biologists and geographers (MACHOWSKI, 2010).

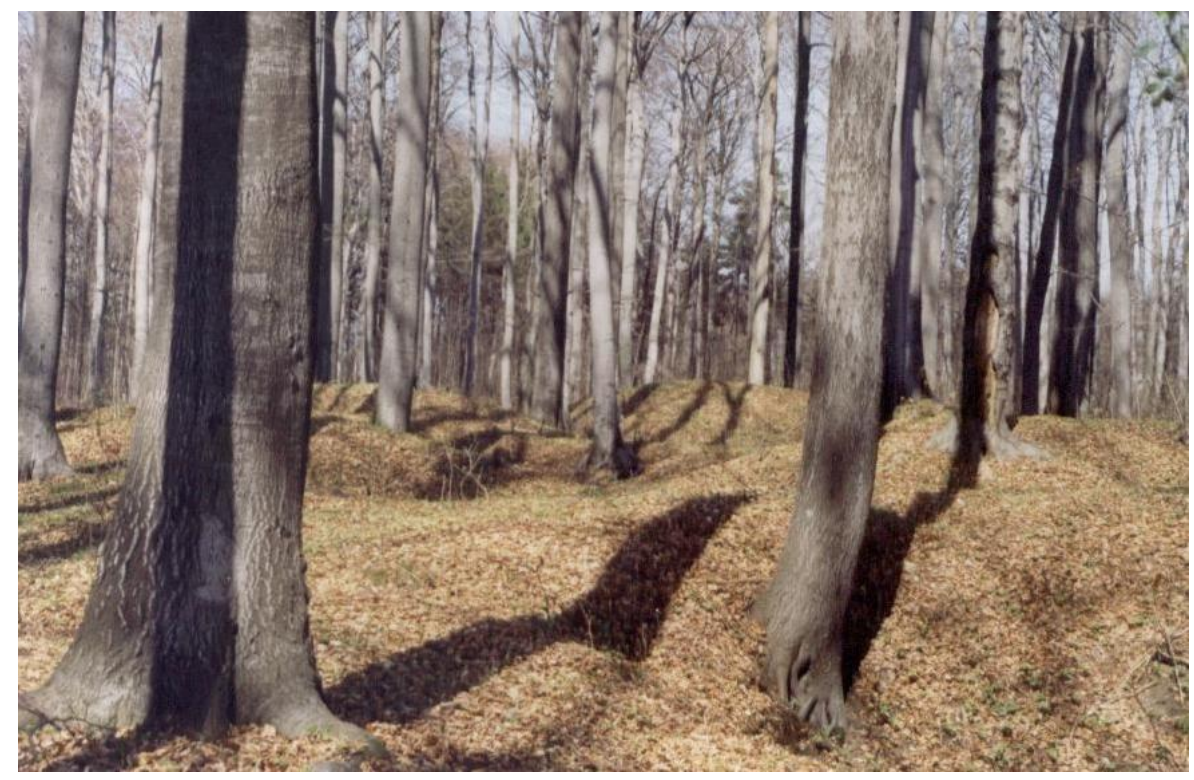

Fig. 2. Abandoned workings and subsidence in the natural reserve "Segiet" in Bytom (M. Lamparska) 


\subsection{Places adapted for recreation}

The second group of historical mining sites in the Katowice conurbation comprises of places adapted for recreation. The former quarries and mines - due to the interesting relief and aesthetic features of the landscape, have been turned into recreation areas. Grota Park in the district of Bytom Sucha Góra was established in the area of abandoned quarries and flooded opencast mines of iron, zinc and lead ores. Today it is a place of worship. The area is a park and the water reservoirs are under the care of anglers.

A group of four water reservoirs developed in former backfilling sand excavations - "Pogoria IIV" in Dąbrowa Górnicza is another example of adaptation for recreational purposes (DULIAS, 2010). There is the "Dolomite valley" in Bytom an all-year ski sports centre located in a former dolomite quarry (PEŁKA-GoŚCINIAK, 2006). In the area of the quarry there is a documentation site of inanimate nature "Blachówka".

\subsection{Places documenting changes in the groundwater environment}

There are many objects in the Katowice conurbation that document the scale of transformations of the surface and groundwater environment that have been caused by the development of mining over the last 200 years. The representative examples include: an artificial riverbed of the Szarlejka transferred in the nineteenth century and the canal partially running under the housing estate Szarlej in Piekary Śląskie. The river bed of the Szarlejka was transferred to avoid interference with the opencast mine "Szarlej" - now it is a landscape axis of reclamation work associated with the recovery of the former mine site to use it for other non-mining purposes (LAMPARSKAWIELAND, 2003, 2004). The Kochłowice stream flows under the buildings of the "Bielszowice" colliery. It can become a tourist trail when the coal exploitation has finished and some necessary adaptation work has been done (LAMPARSKA-WIELAND, 2004).

The high bank of the Przemsza River, from the beginning of the industrial revolution to the beginning of the World War II, was an industrialized area - the coal excavated there was sent by water transport to Cracow and Warsaw. The transportation was provided by barges and Mysłowice was an important inland port on the Przemsza. The port facilities were a part of the river engineering and the port itself was located in the so-called "Triangle of Three Emperors". The outlets of the adits which occur there can be restored and become a document, or a proof of the splendour of the port. In the area of Upper Silesia, drifts in coal mines were used for gravitational drainage of water from the deposits. A tunnel consisted of an underground section and a surface one called "roznos" which was in fact an artificial valley where water was flowing from a mine to the nearest river valley. "Roznos" of the Lazarus adit is the only surviving "roznos" of a water adit. It is now used for municipal purposes as part of a sewage system (LAMPARSKA-WIELAND, 2001).

\subsection{Characteristic features of the Silesian landscape, places commemorating stages of mining development}

Mining shafts are indispensable elements of the Silesian landscape. With the increase of production, winding towers were constructed over the shafts. First they were made of bricks, then - since the middle of the nineteenth century - slim silhouettes of steel towers appeared (JAROS, 1984; KosSUTH, 1965). The winding tower "Krystyna" in Bytom ("Szombierki Coal Mine", Fig. 3) and the tower above the shaft "Andrzej" in Ruda Śląska ("Pokój Coal Mine") are examples of brick towers. Steel winding towers, the icon of Upper Silesia, were of a very different in shape at the beginning, the modern shape appeared at the end of the nineteenth century. It happened very rarely that a tower was constructed of reinforced concrete. The winding tower in the "President Coal Mine" in Chorzów has such a structure (KRYGIER ET AL., 1971).

The housing estates, Nikiszowiec and Giszowiec, in Katowice are the most famous examples of working class settlements in the area of Upper Silesia. The urban and spatial arrangement of Nikiszowiec was designed and built between 1908 and 1918. It became a historical monument in 2011. Ficinus in Ruda Śląska, Borsiga housing estate in Zabrze Biskupice, or the housing estate in Bytom Bobrek, can be considered as other examples of such sites.

Plaques made to honour and commemorate the miners who died in mining disasters, especially in the coal mine "Kleofas", which was finally placed in St. Joseph church in Katowice-Załęże, may be also treated as historic sites. Plaques, or even crosses, used to be placed in many mines to commemorate the struggle for freedom, for example the one in "Wujek Coal Mine". However, they have become a part of other historic routes. There is a special monument in this group. It is a stone which marks benchmark 0 in Sucha Góra network - the starting benchmark of the geodetic control network which is still used nowadays. It will be replaced by the 2000 network in the near future. 


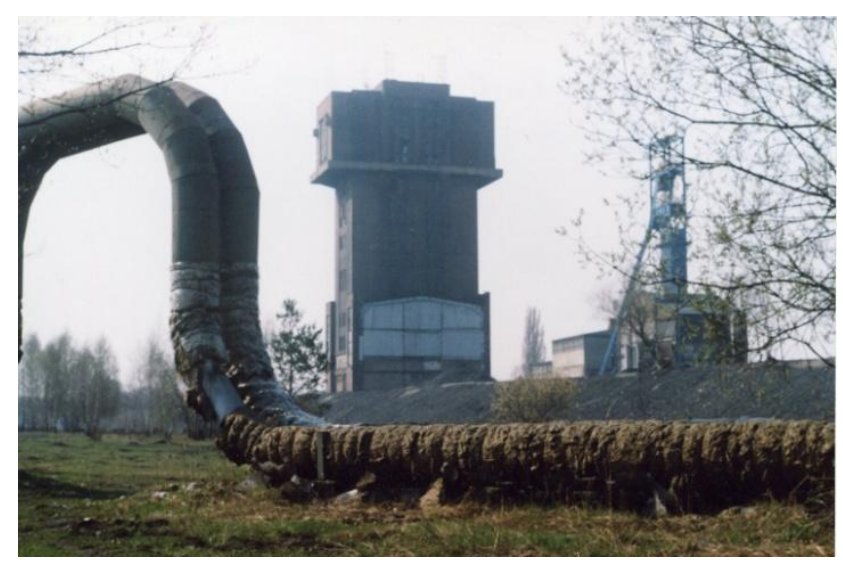

Fig. 3. Winding towers in the closed "Szombierki Coal Mine" in Bytom: "Krystyna" (brick construction) and "Janina" (steel construction) (M. Lamparska)

\subsection{Post-mining facilities adapted for service, commercial, and residential purposes}

Some post-mining facilities have been adapted for service, commercial and residential purposes, for example, the shaft "Bolek" in Bytom, a group of buildings of the closed "Katowice Coal Mine", buildings of "Gliwice Coal Mine", the pumping station in "Kleofas Coal Mine" the building of the historic baths in "Concordia Coal Mine" in Zabrze (Fig. 4). The residential loft on the shaft "Bolek" is the most famous among them, the only one its type in Silesia. Other objects are still waiting to be adapted, but most of all are waiting for sponsors.

\subsection{Museums and open-air mining museums}

The last category of mining sites comprises surface and underground mining museums. They document the life and work of miners, as well as recreate underground conditions in a mine. In Upper Silesia, there are a few such museums and Memorial Chambers. The Museum of Coal Mining in Zabrze, which for many years has been building up a large collection of equipment gathered from liquidated mines, is the most important one. A part of the drifts of "Królowa Luiza" (Queen Louise) and Mining Heritage Park Guido also belong to the museum (LAMPARSKA - WIELAND ET AL., 2002). Both sites protect machinery and equipment that are still in good working order and they are ready to demonstrate old and modern mining techniques. Launching the revitalization of the mine "Królowa Luiza" (Queen Louise) is an important initiative. Together with the "Carnall" shaft and Underground Heritage Park "Królowa Luiza" (Queen Louise) they will create a big coal mining heritage park, making the town a place where mining traditions and culture are still cherished. Similar activities can be observed in many

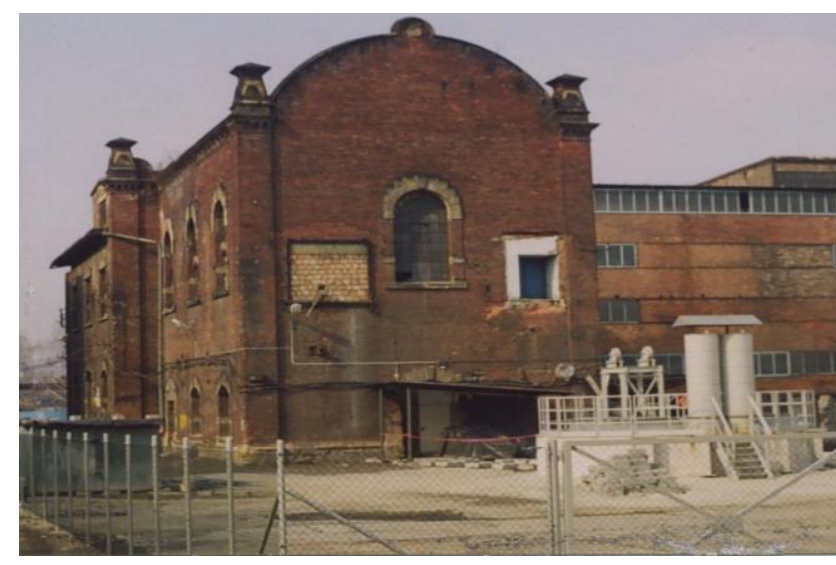

Fig. 4. Historic baths in "Concordia Coal Mine" in Zabrze (M. Lamparska)

cities in France - especially in Lorraine and Germany (Kostrubiec \& LAMPARSKA - WiELAND, 2005).

\section{Summary}

The described post-mining sites exist in different parts of the Katowice conurbation; therefore, linking them by tourist trails and establishing protected landscape areas around them will be a really crucial task in the future. Such measures have already been taken, for example, in Bytom, Chorzów and Zabrze. By analysing the particular post-mining sites, it can be concluded that material remains of industrial culture are preserved within the Katowice conurbation, despite their diversity, and form a group of monuments, complementary to those found in the rest of industrialized Europe. Hence, the industrial heritage in the area of the Katowice conurbation is an important part of the European, supranational heritage.

\section{References}

Cabała S., Orczewska A., Zaufal T. 2006. Stan zachowania zbiorowisk lasów bukowych w Górnośląskim Okręgu Przemysłowym i perspektywy ich ochrony. Kształt. środ. geogr. i ochr. przyr. na obsz. uprzem. i zurb., 37: 5-16.

Dulias R. 2008. Changes in landscape in the neighbourhood of Żabie Doły in the Silesian Upland. Anthropogenic aspects of landscape transformations, 5: 13-19.

Dulias R. 2010. Landscape planning in areas of sand extraction in the Silesian Upland, Poland. Landscape Urban Plan., 95: 91-104.

Dwucet K., Pukowska-Mitka M. 2007. Dziedzictwo przemysłowe Górnego Śląska jako element atrakcyjności turystycznej regionu. [in:] Kurek W., Faracik R. (eds.) Studia nad turystyką. Prace geogr. i region., WGiGP UJ, Kraków: 43-54.

Jaros J. 1984. Słownik historyczny kopalń węgla na ziemiach polskich. ŚIN, Katowice.

Kossuth S. 1965. Górnictwo węgla na Górnym Śląsku w połowie XIX wieku. Śląsk, Katowice. 
Kostrubiec B., Lamparska-Wieland M. 2005. Mining tourism in hard coal basins in Poland and France. [in:] Wyrzykowski J (ed.) Condition of the Foreign Tourism Development in Central and Eastern Europe, vol. 8, Univ. of Wroclaw, Wrocław: 97-110.

Krygier E., Molenda D., Sałacik S. 1971. Katalog zabytków budownictwa przemysłowego w Polsce. Zabytki górnicze, t. 3, z. 4, PAN, Warszawa.

Lamparska-Stobiecka M. 2008. Górnicze dziedzictwo GZM. [in:] Dulias R., Hibszer A. (eds.) Górnośląski Zwiq̨zek Metropolitalny. Zarys geograficzny. PTG Oddz. Katowice, Sosnowiec: 255-264.

Lamparska-Wieland M. 2001. Sztolnie odwadniające na Śląsku jako element atrakcyjności turystycznej regionu. Budown. Górn. i Tunelowe, 1, WG, Katowice: 23-26.

Lamparska-Wieland M. 2003. Zmiany wybranych elementów krajobrazu Płaskowyżu Tarnowickiego. WNoZ UŚ, nr 27, Wyd. UŚ Katowice.
Lamparska-Wieland M. 2004. Sztolnie wodne Katowic. Kształt środ. geogr. i ochr. przyr. na obsz. uprzem. i zurb., 35: 22-28.

Lamparska-Wieland M. 2006. Postmodernistyczne krajobrazy Europy: Śląsk i Zagłębie Ruhry. [in:] Myga-Piątek U. (ed.) Krajobrazy przemysłowe, poprzemysłowe i poeksploatacyjne. Prace Kom. Krajobrazu Kulturowego PTG, Sosnowiec: 34-35.

Lamparska-Wieland M., Srokosz Z., Lamparski H. 2002. Odtworzenie Kopalni Doświadczalnej Węgla Kamiennego M-300 w Zabrzu oraz jej przekształcenie w skansen górnictwa podziemnego „Guido”. Przegl. Górn., 6: 30-38.

Machowski R. 2010. Przemiany geosystemów zbiorników wodnych powstałych w nieckach osiadania na Wyżynie Katowickiej. Wyd. Uniw. Śl., Katowice.

Pełka-Gościnak J. 2006. Restoring nature in mining areas of the Silesian Upland (Poland). Earth Surface Processes Landforms, 31, 13: 1685-1691.

Solarski M. 2013. Anthropogenic transformation of the Bytom area relief in the period of 1883-1994. Environ. \& Soc. econ. Stud., 1,1:1-8. 